Kuyumcu Vardar, A. ve Arsal Z. (2014). Öz-düzenleme Stratejileri Öğretiminin Öğrencilerin İngilizce Başarılarına ve Tutumlarına Etkisi. Ana Dili Eğitimi Dergisi, 2(3), 32-52.

Ana Dili Eğitimi Dergisi
Journal of Mother Tongue Education
ADED - JOMTE
www.anadiliegitimi.com

\title{
Öz-düzenleme Stratejileri Öğretiminin Öğrencilerin İngilizce Başarılarına ve Tutumlarına Etkisi* $^{*}$
}

\author{
Aslihan KUYUMCU VARDAR ${ }^{* *}$ \\ Zeki $A R S A L^{* * *}$ \\ Özet
}

\begin{abstract}
Bu çalışmada öz-düzenleme stratejilerine göre düzenlenen İngilizce dersinin öğrencilerin başarılarına ve tutumlarına etkisi incelenmiştir. Araştırmada deneysel yöntemin öntest-sontest kontrol gruplu deseni kullanılmıştır. Öğrencilerin İngilizce dersindeki başarıları ve İngilizce dersine yönelik tutumları araştırmanın bağımlı değişkenlerini oluşturmaktadır. Bu bağımlı değişkenler üzerindeki etkisi araştırılan bağımsız değişken ise araştırmacı tarafından öz-düzenleme stratejileri temel alınarak hazırlanan etkinliklerdir. Uygulama, 2008-2009 öğretim yılı, bahar yarıyılında, Düzce Üniversitesi, Teknik Eğitim Fakültesi Mobilya ve Dekorasyon (23) ve Elektrik Eğitimi (24) bölümlerinin 1. Sınıf öğrencileri ile yürütülmüştür. Çalışmada, üç veri toplama aracı kullanılmıştır. Bu araçlar "İngilizce Hazırbulunuşluk Testi, İngilizce Başarı Testi ve İngilizce Tutum Ölçeği"dir. Öz-düzenleme stratejilerine göre düzenlenmiş ve sekiz hafta süren İngilizce dersi sonunda şu bulgulara ulaşılmıştır: Uygulama sonrasında İngilizce öğretiminde öz-düzenleme stratejileri kullanımına bağlı olarak öğrenci başarısının anlamlı düzeyde yüksek olduğu görülmüştür. Buna karşılık deney ve kontrol grupları arasında İngilizceye yönelik tutum puanlarında anlamlı bir farklılık bulunmamıştır.
\end{abstract}

Anahtar Kelimeler: Öz-Düzenleme Stratejileri, İngilizce Öğretimi, İngilizce Akademik Başarı, Tutum

\section{The Effect of Self-Regulated Learning Strategies Instruction On Students'}

\section{English Achievement and Attitude}

\begin{abstract}
This study aims to investigate the effects of English instruction including self-regulated learning strategies on students' English achievement and attitude towards lesson. Pre-test-post-test control group design of experimental method was used in the study. The dependent variables consist of English achievement and attitude towards English. The independent variable of which effects on dependent variables investigated is the English instruction prepared by the researcher based on self-regulated learning. The instruction included the first classes of Furniture and Decoration (23) and Electrical Education (24) departments of Düzce University, Faculty of Technical Education, in 2008-2009 Academic year. Three data collection instruments were used in the study. These were; the Achievement Test, Readiness Test which were prepared by the researcher and English Attitude Scale. The following findings were obtained after eight weeks of English instruction which was integrated with self-regulated learning strategies: English achievement of the sample group increased significantly depending on the instruction integrated with self-regulated learning strategies. No significant difference was found in the points of English Attitude Scale between control and sample groups.
\end{abstract}

Key Words: Self-regulated learning strategies, English instruction, English Achievement, Attitude

\footnotetext{
${ }^{*}$ Bu çalışma, 2011 yılında Abant İzzet Baysal Üniversitesi, Eğitim Bilimleri Enstitüsü, Eğitim Programları ve Öğretimi alanında doktora tezi olarak sunulan çalışmanın bir bölümünü içermektedir.

${ }^{* *}$ Yrd. Doç. Dr., Düzce Üniversitesi, Eğitim Fakültesi, Eğitim Bilimleri Bölümü, Düzce. E-posta: aslihankuyumcu@duzce.edu.tr

${ }^{* * *}$ Doç. Dr. Abant İzzet Baysal Üniversitesi, Eğitim Fakültesi, Eğitim Bilimleri Bölümü, Bolu. E-posta: arsal z@ibu.edu.tr
} 


\section{Öz-düzenleme Stratejileri Öğretiminin Öğrencilerin İngilizce Başarılarına ve Tutumlarına Etkisi}

\section{Giriş}

Ingilizce, iletişim, bilim ve ekonominin ortak dilidir. Dolayısıyla bu ortak dil, dünyada her zaman öğrenilmesi tercih edilen bir konumda olmuştur. Bu durum, yabancı dil öğretiminin etkililiği ile ilgili birçok araştırma yapılmasına da neden oluşturmuştur.

Yabancı dil öğretiminde son yirmi yıl içinde yapılan çalışmalar, yabancı dil öğrenme stratejileri üzerinde yoğunlaşmaktadır. Bu çalışmaların temel amaçları, yabancı dil öğrencilerini öğrenmeyle ilgili daha öz-denetimli ve etkili hale getirmek şeklinde özetlenebilir. Araştırmalar, strateji bilgisine sahip dil öğrencilerinin diğerlerine kıyasla daha etkili, daha çok kaynak kullanan, daha esnek ve dili daha kolay edinen öğrenciler oldukları yönünde sonuçlar ortaya koymaktadır. Öğrenciler çeşitli öğrenme stratejilerini geliştirir, kişiselleştirir ve kullanırlarsa dil yeterliliği kazanmaları daha kolay olmaktadır. Kendi öğrenmesinde sorumluluk alan öğrencilerin yabancı dili öğrenme eğilimi daha yüksektir (Tseng, Dörnyei and Schmitt, 2006).

Bilgi, beceri, yetenek ve daha genel olarak öğrenmeyle ilgili kavramların yapısıyla ilgili mevcut nörobiyolojik gelişmeler, öğrenme stratejilerinin kullanımını oluşturan davranışları yeterli miktarda tanımlayamamaktadır. Bunun sonucunda öğrenme stratejilerini hedef alan eğitim psikolojisi araştırmaları 1990'lı yıllarda fark edilir bir şekilde azalmıştır. Araştırmacılar artık öz-düzenlemeyle ilgili çalışmalara yönelmişlerdir. Bu kavramın hem öğrenme stratejileriyle hem de bireysel farklılıklarla doğrudan ilişkileri bulunmaktadır (Dörnyei, 2005; 190).

1990'I yılların başında ortaya çıkan bu değişikliğin özellikle iki boyutu çok önemlidir:

a) Öz-düzenlemeyle ilgili yeni perspektif, daha önceki öğrenme stratejilerinden daha geniş bir bakış açısını içermektedir. Bu durum, akademisyenlere öz-düzenlemenin sadece öğrenmeyle sınırlı olmayan diğer bilişsel ve davranışsal süreçleriyle bağlantılar kurma olanağını vererek disiplinlerin karşılıklı olarak kullanılmasını sağlamıştır. Özellikle Boekaerts, Pintrich ve Zeidner'in Öz-Düzenleme El Kitabı (2000) bu çalışmanın bir ürünüdür (Dörnyei, 2005; 190).

b) Odağın üründen sürece doğru kaymasıyla, araştırmacılar kendileri için daha çok hareket alanı yaratmışlardır: Sözde öz-düzenleme mekanizmaları öğrenme stratejilerine oldukça benzemesine ve aynı problemleri içermesine rağmen, bu mekanizmalar, öz-düzenlemenin diğer boyutlarının da incelenmesini sağlamıştır (Dörnyei, 2005; 191).

Öz-düzenleme akademik başarılara yönelik bir yaklaşımdır. Yaşı, cinsiyeti, etnik kökeni, yetenek düzeyi, ön bilgisi veya motivasyonu ne olursa olsun, her öğrenci öz-düzenleme stratejilerini öğrenebilir ve bu stratejileri akademik hedeflerine ulaşmada kullanabilir (Baharom, 2003).

1980'li yıllarda etkin bir şekilde ortaya çıkan öz-düzenlemeyle öğrenmede, öğrencilerin 
öğrenme stratejilerini izlemesi ve düzenlemesi esastır. Öz-düzenlemeyle öğrenme, bireyin bilişini, duygusunu, etkinliğini ve çevresini içeren çok boyutlu bir olay olduğu için, öğretmenlerin öğrencilerine, kendilerini değerlendirme, hedef belirleme, öğrenme stratejileri, motivasyon ve kendini izlemeyle ilgili önerilerde bulunmaları gerekmektedir (Cheng, 2011).

Çalışmalar başarılı öğrencilerin öz-düzenleme becerilerinin, başarısız olan öğrencilere kıyasla daha yüksek olduğunu göstermektedir. Zimmerman, eğitim psikolojisi alanında ilk olarak özdüzenlemeden bahseden bilim adamıdır ve öz-düzenleme becerisinin, öğrencilerin performansı ile ilgili en iyi yordayıcı olduğunu savunmaktadır (Cheng, 2011).

Zimmerman (2001)'a göre öz-düzenleme, öğrencilerin, biliş bilgisi, motivasyon ve davranış boyutlarını kendi öğrenme süreçlerine etkin bir şekilde katma düzeyini ifade eden çevrimsel bir süreçtir. Pintrich (2000) öz-düzenlemeyi, öğrencilerin öğrenme hedefleri belirledikleri ve daha sonra bilişlerini ve davranışlarını düzenledikleri ve kontrol ettikleri yapılandırmacı bir süreç olarak tanımlar. Turingan ve Yang (2009), buna ek olarak öğrencilerin kendi öğrenmelerinin sorumluluklarını aldığı, bilişsel stratejiler, biliş bilgisi ve motivasyonu daha bütüncül bir yapıyla ele alarak bu güçler arasındaki etkileşim üzerinde durur.

Öz-düzenlemeyle öğrenme yaklaşımını, daha önceki öğrenme ve başarı modellerinden ayıran en önemli özellik, öğretmenlere etkinliklerini hazırlarken veya planlarken sağladığı öğretimsel etkilerdir. Bu bakış açısı sayesinde eğitim analizleri, okulda ve evde öğrencinin öğrenme becerilerinden, bireysel olarak yönetilen ve öğrenme ürünlerini ve çevreyi şekillendiren stratejilere doğru yön değiştirmiştir. Öz-düzenleme sürecinde, öğrenci strateji seçimini bizzat kendi yapmakta, yapılandırmakta hatta uygun öğrenme ortamını kendi oluşturmaktadır. Aynı zamanda öğrenci ihtiyaç duyduğu öğretimin şeklini ve miktarını seçmede aktif bir rol oynamaktadır (Zimmerman, 2001, 3-5).

Genel olarak öz-düzenleme kavramı, bireylerin hedefler belirlediği, hedefleri gerçekleştirmek için uygun bilişsel, biliş̧ bilgisel ve motivasyonel stratejileri seçtikleri, performanslarını izleyip değerlendirdikleri ve gelecekteki öğrenmelerine yön verdikleri çevrimsel bir süreç olarak özetlenebilir.

Öz-düzenleme stratejileri, bilişsel, biliş bilgisi, kaynakları yönetme ve motivasyon stratejileri olarak aşağıda açıklanmıştır.

\section{Bilişsel Stratejiler}

Bilişsel stratejiler, öğrencinin akademik görevleri gerçekleştirmede ya da sosyal becerilerini ilerletmede kullandığı bir grup stratejidir. Bilişsel stratejilerin kullanımı, bir öğrencinin herhangi bir öğrenme durumundaki verimini artırır. Öğrencinin ders içeriğindeki bilgiyi hatırlaması ve kullanması, cümleleri ve paragrafları yapılandırması, bir metni düzeltmesi, özetlemesi ve öğrenilen bilginin kategorize edilmesi bilişsel stratejilere örnek olarak gösterilebilir (Rosenshine, 1997). 


\section{Öz-düzenleme Stratejileri Öğretiminin Öğrencilerin İngilizce Başarılarına ve Tutumlarına Etkisi}

Bilişsel öğrenme stratejileri kapsamında tekrar, eklemleme ve örgütleme stratejileri sınıftaki akademik performans için önemli olarak tanımlanmıştır. Tekrar stratejileri, öğrenilecek materyalin ezberlenmesini veya yüksek sesle tekrarı içerir, bir metnin altının çizilmesi de basit anlamda tekrar olarak düşünülebilir. Bu stratejiler, öğrencilerin metinlerdeki veya listelerdeki bilgileri seçmelerini ve kısa süreli bellekte bilginin etkin şekilde korunmasını sağlar. Eklemleme ve örgütleme stratejilerine daha çok zaman harcanır. Öğrenilecek materyalin özetini çıkarma veya açıklama, genellemeler yapma, anlamlı not alma, soru sorma ve cevap verme eklemleme stratejilerine örnektir. Örgütleme stratejileri, metinden ana fikri seçmek, ana hatlarını belirlemek ve fikirleri seçmek ve düzenlemek için kullanılan birçok tekniği içeren davranışlardan oluşur. Tekrar stratejilerinin aksine öğrenilecek materyalin daha derinlemesine kavranmasını sağlar (Weinstein ve Mayer, 1986; Akt. Hofer, L.Yu ve Pintrich, 1998, 6667)

\section{Biliş Bilgisi Stratejileri (Metacognition)}

Biliş bilgisi, kişinin kendi düşünme süreçlerinin farkında olması ve bu süreçleri kontrol edebilmesi anlamına gelmektedir (Flavell, 1979). Biliş bilgisi stratejileri; yeni bilgileri daha öncekilerle birleştirme, düşünce stratejileri seçme, düşünce süreçlerini planlama, izleme ve değerlendirme şeklindedir. Buna yönelik davranışlar geliştirmek için; neyi bilip bilmediğimizi belirlemek, düşünce hakkında konuşmak, planlama ve öz-denetim yapmak, düşünce süreçlerini sorgulamak ve kendini değerlendirmek gerekmektedir (Hacker, Dunlosky ve Graesser, 1998)

Drmrod'a (1990) göre bu yeteneklere sahip olan bir öğrenci; kendi öğrenme sürecinin, belleğinin ve hangi görevlerin tamamlanması gerektiğinin farkındadır, öğrenme yöntemlerinden etkili olanlarını bilir, başarı için gereken işlemleri planlar, öğrenme stratejilerini etkili şekilde kullanır, öğrenme durumunu izler ve ön bilgilerini yeni görevlerde etkin hale getirir. Öğrencilerin kendi öğrenmelerini düzenlemelerine, yürütmelerine ve denetlemelerine yön veren biliş bilgisi stratejileri bir anlamda kendi düşünmeleri üzerine düşünmeyi içermektedir (Arends, 1997).

\section{Kaynakları Yönetme Stratejileri}

Pintrich ve arkadaşları tarafından ortaya konan öz-düzenleme modelinin önemli bir bileşeni kaynakları yönetme stratejileridir. Bu stratejiler, öğrencilerin hedeflere ulaşırken kullanacakları kaynakların düzenlenmesini içerir. Zaman ve çalışma ortamının düzenlenmesi, çabanın düzenlenmesi ve yardım arama boyutları bulunmaktadır. Zamanını ve çalışma ortamını en verimli şekilde düzenleyen, bir hedefe ulaşma sürecinde çabasını ve emeğini kontrol altına alan, gerektiğinde arkadaşlarından veya öğretmeninden yardım almasını bilen öğrenciler akademik anlamda daha başarılıdırlar (Pintrich ve diğerleri, 1991). Kaynak yönetim stratejileri, öğrencilerin sahip oldukları ön bilgiye ve bağlamlarında 
kullanabilecekleri kaynaklara göre farklılık gösterebilir. Kaynak yönetim etkinlikleri doğrudan bilişsel veya biliş bilgisel etkinliklere bağlı değildir fakat akademik başarı için önemlidir (Pintrich, 1999).

Yüksek başarı düzeyine sahip olan öğrencilerin daha çok öz-düzenleme stratejilerini kullandıkları, intiyaç duyduklarında yardım aldıkları, zaman ve çalışma ortamlarını daha iyi düzenledikleri ve çaba düzenlemesini daha etkin olarak yaptıkları söylenebilir (Chen, 2002).

\section{Motivasyon}

Genelde sınıf ortamında oldukça etkili sonuçlanan öz-düzenleme uygulamalarını daha az yapılandırılmış ortamlarda olumlu sonuçlandırmak zordur. Bu sınırlılık araştırmacıları öğrencilerin özdüzenlemeye kaynak olarak kullandıkları motivasyon boyutunu incelemeye yönlendirmiştir. Burada hedef belirleme, yüklemeler, öz-yeterlik inançları, ürün beklentileri, sosyal kaynaklar, değerler ve ilgiler önem kazanmaktadır (Zimmerman ve Schunk, 2007, 2).

Yüksek düzeyde motivasyona sahip olan öğrenciler, diğerlerine göre daha iyi bir performans göstererek gelişim sağlarlar (Zimmerman ve Kitsantas, 1999, Akt. Zimmerman ve Schunk, 2007, 3). Özdüzenleme uygulamaları, motivasyonu olumlu etkilemesine rağmen bireysel başarının elde edilmesinde tek başına yeterli olmayabilir. Genelde çok özenli uygulamalar gerektirir. Bununla beraber öz-düzenleme uygulamaları, öğrenme ürünleri kadar öğrencilerin öz-yeterlik inançları gibi motivasyonlarını artırıcı uygulamalarla beraber yürütülebilir (Schunk ve Pajares, 2005). Öğrencilerine zorlayıcı görevler, başarılması mümkün ve anlamlı etkinlikler sağlayan ve onların çabalarını destekleyip cesaretlendiren öğretmenler, öğrencilerin kendi inisiyatiflerine dayanan sağlam bir öz-yeterlik duygusunu geliştirmelerini sağlayacaklardır (Pajares, 2007, 134).

Öğrencilerin öz-düzenleme süreçleri ve motivasyonel inançları arasında karşılıklı bir etkileşim olduğuyla ilgili birçok bulgu bulunmaktadır. İlginç öğretim etkinliklerinin seçilmesi, öğrencilerin olumlu şekilde desteklenmesi, övülmesi, başarı için ödüller verilmesi ya da öğrencilerin daha özgür bırakılması, eğitimcilerin motivasyonu artırmak için kullandıkları yöntemlerdendir ve her birinin öğrenme üzerinde olumlu anlık etkileri bulunmaktadır. Bununla beraber, her bir yöntemin başarının ödüllendirilmesinin, ödüllendirilmediği durumlarda isteksizlik yaratması gibi eleştirilen noktaları bulunmaktadır (Zimmerman ve Schunk, 2007, 4).

Motivasyon süreci, öz-düzenlemeyle öğrenmeyi kolaylaştırır, bu da performans gibi bilişsel, keyif almak gibi duyuşsal ve devam eden motivasyon şeklinde motivasyonel ürünlerle sonuçlanır (Lens ve Vansteenkiste, 2007, 143). 


\section{Öz-düzenleme Stratejileri Öğretiminin Öğrencilerin İngilizce Başarılarına ve Tutumlarına Etkisi}

\section{Öz-Düzenleyici Öğrencilerin Özellikleri}

Öz-düzenleme ile öğrenciler öğrenmelerini üç boyutta düzenleyebilirler. Bunlar gözlemlenebilir davranışları, motivasyon ve bilişleridir. Öncelikle, öz-düzenleme yapan öğrenciler davranışlarını, motivasyonlarını ve bilişlerini kontrol edip durumun gerektirdiği koşullara göre düzenleyip ayarlama yaparlar. İkinci önemli bileşen, öğrencinin ulaşmak istediği bir hedefi olması ve bu hedefe yönelik performansını izleyip değerlendirmesidir. Üçüncü önemli bileşen de, öğretmen ya da velinin değil, bizzat öğrencinin kendi hareketlerini kontrol etmesidir. Özet olarak öz-düzenlemeyle öğrenme, akademik bir işle ilgili, amaca yönelik davranışın, motivasyonun ve bilişin öğrenci tarafından kontrol edildiği bir süreci içerir. Davranışın öz-düzenlemesi, zaman, çalışma ortamı ve akranların işbirliği gibi öğrencilerin sahip olduğu kaynakların aktif şekilde kontrolünü içerir. Motivasyonun özdüzenlemesi, yeterlik ve hedefe yönelme gibi öğrencilerin motivasyonel inançlarının kontrol edilmesi ve değiştirilmesini içerir. Buna ek olarak kaygı gibi duyguların kontrol edilmesini ve öğrenmeyi olumlu şekilde etkilemesi için bazı değişiklikler yapılmasını sağlar. Üçüncü olarak bilişin öz-düzenlenmesi de öğrenme için gereken çeşitli bilişsel stratejilerin kontrolünü içerir (Pintrich, 1995, 5-7).

Öz-düzenleme becerisi yüksek olan öğrenciler, düşük olanlara kıyasla daha iyi öğrenme hedefleri seçer, daha etkili öğrenme stratejilerini uygular, hedefe ulaşma süreçlerini daha iyi izler ve değerlendirir, öğrenme için daha üretici bir çevre oluşturur, gerektiğinde kolaylıkla yardım arar, daha çok çaba sarf eder, daha kararlıdır, hedefine ulaştığında daha etkili yeni hedefler belirlerler. Bu öğrenciler (Zimmerman ve Schunk, 2007, 1-2);

1. Tekrar, detaylandırma ve düzenleme gibi bilginin depolanmasını ve öğrenilmesini sağlayan bir dizi bilişsel stratejiden haberdardırlar ve nasıl kullanılacağını bilirler.

2. Bireysel hedeflerini gerçekleştirmek amacıyla, zihinsel süreçlerini nasıl planlayacaklarını, kontrol edeceklerini ve yönlendireceklerini bilirler.

3. Yüksek düzeyde akademik öz-yeterliğe sahiptirler ve öğrenme hedeflerini benimseyerek görevlere yönelik olumlu duygu geliştirirler ve ihtiyaca uygun olarak bütün motivasyonel inançlarını düzenlerler.

4. Herhangi bir görevle ilgili zaman ve çaba yönetimini iyi yaparlar. Aynı zamanda ideal çalışma ortamını hazırlama ve gerektiğinde öğretmen veya arkadaşlarından yardım alma konularında başarılıdırlar.

5. Çalışma ortamı elverdiği ölçüde, akademik görevlere katılımda oldukça isteklidirler.

6. Akademik görevleri gerçekleştirirken, konsantrasyonlarını, çabalarını ve motivasyonlarını korumada yüksek irade gösterirler. 
Genel olarak öz-düzenleme becerisine sahip olan öğrencilerin, bilişsel farkındalıklarının ve özyeterlik düzeylerinin yüksek olduğu, hedef planlamalarını iyi yaptıkları, etkili bir zaman ve çaba yönetimi gerçekleştirdikleri ve yüksek motivasyona sahip oldukları görülmektedir.

Genelde, yabancı dil öğrenmede başarılı olan öğrenciler öğrenmelerinde kendi kararlarını vermektedir. Araştırmacılar, bu öğrencilerin öz-düzenleme süreçlerine ve belirgin öğrenme kapasitelerine ağırlık vererek, stratejik öğrenci olmanın sırrını açıklamaya çalışmışlardır. Bu öğrencileri stratejik öğrenci yapan şey yaptıkları değil, kendi öğrenmelerini geliştirmek için ne tür yaratıcı bir çabayı seçtikleridir. Dolayısıyla araştırma literatüründe çoğunlukla karmaşaya neden olan strateji kelimesi yerine daha güncel olan öz-düzenleme stratejisi kullanılmıştır (Macaro, 2001).

Öğrencilerin yabancı dille etkileşimde bulundukları anda kendi öğrenmelerini denetlemelerini sağlamak, yabancı dil öğretimindeki ideal ve sık rastlanılan bir hedeftir. Bağımsız öğrenme, tüm bilişsel ve duyuşsal faktörlerden etkilenmektedir. Bağımsız öğrenme, etkili öz-düzenlemeye bağlıdır (Leaver, Ehrman ve Shekhtman, 2005). Bu çalışmanın amacı, öz-düzenleme stratejileri öğretiminin, öğrencilerin İngilizce dersindeki akademik başarılarına ve İngilizceye yönelik tutumlarına etkisini belirlemektir. Bu amaç doğrultusunda aşağıdaki sorulara cevap aranmıştır.

1. Deney ve Kontrol grubunun İngilizce başarı ön test puanları kontrol altına alındığında, son test puanları arasında anlamlı bir farklılık var mıdır?

2. Deney ve Kontrol grubunun uygulama öncesi İngilizce dersine yönelik tutum ölçeğinden alınan puanları kontrol altına alındığında, uygulama sonrasında elde edilen ölçek puanları arasında anlamlı bir farklılık var mıdır?

\section{Yöntem}

Bu araştırmada deneysel yöntemin ön-test-son-test kontrol gruplu deseni kullanılmıştır. Öntest-son-test kontrol gruplu araştırma deseni eğitim ve psikolojide en sık kullanılan deneysel desenlerden biridir. Bu desende aynı denekler üzerinde ölçümler yapıldığından, farklı deneysel işlem koşulları altında elde edilen ölçümler pek çok deneyde yüksek düzeyde ilişkili olacaktır. Bu da hata payını düşürmekte ve buna bağıı olarak istatistiksel gücü artırmaktadır (Ferguson ve Takane, 1989; Kirk, 1968; Akt. Büyüköztürk ve diğerleri, 2010, 202)

$\mathrm{Bu}$ çalışmada öz-düzenleme stratejileri öğretiminin öğrencilerin İngilizce dersindeki başarılarına ve tutumlarına etkisi araştırımıştır. Öğrencilerin İngilizce dersindeki başarıları ve İngilizce dersine yönelik tutumları araştırmanın bağımlı değişkenlerini oluşturmaktadır. Bu bağımlı değişkenler üzerindeki etkisi araştırılan bağımsız değişken ise araştırmacı tarafından öz-düzenleme stratejileri temel alınarak hazırlanan etkinliklerdir.

Bu çalışmada kullanılan araştırma deseni Tablo 1'de verilmiştir (Kaptan, 1995). 


\section{Öz-düzenleme Stratejileri Öğretiminin Öğrencilerin İngilizce Başarılarına ve Tutumlarına Etkisi}

Tablo 1. Öntest-sontest kontrol gruplu araştırma deseni

\begin{tabular}{|c|c|c|c|}
\hline Gruplar & Ön-test & Deneysel desen & Son-test \\
\hline G 1 & $\begin{array}{l}\text { O1(Başarı testi) } \\
\text { T1 (Tutum) }\end{array}$ & Öz-Düzenleme & $\begin{array}{l}\text { O3 (Başarı Testi) } \\
\text { T3 (Tutum) }\end{array}$ \\
\hline $\mathrm{G} 2$ & $\begin{array}{l}\text { O2 (Başarı testi) } \\
\text { T2 (Tutum) }\end{array}$ & Normal Öğretim & $\begin{array}{l}\text { O4 (Başarı Testi) } \\
\text { T4 (Tutum) }\end{array}$ \\
\hline
\end{tabular}

G1 Deney Grubu

G2 Kontrol Grubu

O1 - O2 Deney ve Kontrol grubu Ingilizce Başarı Ön testi

T1-T2 Deney ve Kontrol grubu İngilizce Tutum Ön Ölçeği

03-O4 Deney ve Kontrol grubu Ingilizce Başarı Son testi

T3-T4 Deney ve Kontrol grubu Ingilizce Tutum Son Ölçeği

\section{Çalışma Grubu}

Araştırmada, 2008-2009 öğretim yılı, bahar yarıyılında, Düzce Üniversitesi, Teknik Eğitim Fakültesinde, Elektronik ve Bilgisayar Eğitimi, Yapı Eğitimi, Tasarım ve Konstrüksiyon Eğitimi, Mobilya ve Dekorasyon Eğitimi ve Elektrik Eğitimi Bölümleri arasından seçilen iki bölümün $(n=47) 1$. Sınıf öğrencileri çalışma grubunu oluşturmaktadır. Bölümlerin seçilmesinde öğretim programının uygunluğu, dersin aynı öğretim elemanı tarafından yürütülmesi, öğrencilerin bir önceki döneme ait olan 2008-2009 güz dönemi notları ölçüt alınmış, bu özellikler açısından denk olan iki bölüm seçilmiştir. Bu bölümler Mobilya ve Dekorasyon Eğitimi ve Elektrik Eğitimi Bölümleridir. Bu bölümlerde gruplar üzerinde İngilizce hazırbulunuşluk düzeyleri, İngilizce dersine yönelik tutumları ve İngilizce dersi başarı puanları açısından denklik çalışması yapılmıştır.

Aşağıda araştırmanın deney ve kontrol gruplarına yer alan öğrencilere ilişkin kişisel bilgilere yer verilmektedir. Buna göre öğrencilerin gruplara göre dağıımları Tablo 2'de, mezun olunan lise türüne göre dağılımları Tablo 3'te, İngilizce kursuna katılma durum ve sürelerine göre dağııımları Tablo 4'te ve İngilizce başarı durumları Tablo 5'te verilmiştir.

Tablo 2. Çalışma grubunda yer alan öğrencilerin gruplara göre dağılımları

\begin{tabular}{lr}
\hline Gruplar & Öğrenci Sayısı \\
\hline Deney Grubu & 23 \\
\hline Kontrol Grubu & 24 \\
\hline Toplam & 47 \\
\hline
\end{tabular}

Araştırmanın deney grubunda 23, kontrol grubunda 24 öğrenci yer almaktadır. Deney ve kontrol gruplarında yer alan öğrenci sayılarının belirlenmesinde öğrencilerin araştırma sürecinin tamamına katılma durumları dikkate alınmıştır.

Tablo 3. Deney ve kontrol gruplarında yer alan öğrencilerin mezun oldukları lise türüne göre dağılımı

\begin{tabular}{lcrrr}
\hline & Deney & \multicolumn{3}{c}{ Kontrol } \\
\hline Lise türü & $\mathrm{f}$ & $\%$ & $\mathrm{f}$ & $\%$ \\
Endüstri meslek & 23 & 100,0 & 17 & 70,8 \\
Teknik lise & - & - & 1 & 4,2 \\
Anadolu meslek & - & - & 6 & 25,0 \\
Toplam & 23 & 100.0 & 24 & 100,0 \\
\hline
\end{tabular}


Tablo 3 incelendiğinde, Deney grubu öğrencilerinin tamamının $(f=23), \quad$ Kontrol grubu öğrencilerinin de $\% 71^{\prime}$ inin ( $f=17$ ) Endüstri Meslek Lisesi mezunu olduğu görülmektedir. Kontrol grubu öğrencilerinin \%4,2'si $(f=1)$ Teknik Lise ve $\% 25^{\prime} i(f=6)$ Anadolu Meslek Lisesi mezunudur.

Tablo 4. Öğrencilerin İngilizce kurslarına katılma durumu ve sürelerine göre dağııımları

\begin{tabular}{llrrrr}
\hline & & \multicolumn{2}{c}{ Deney } & \multicolumn{2}{c}{ Kontrol } \\
\hline \multirow{3}{*}{ Kursa Katılım } & & $f$ & $\%$ & $f$ & $\%$ \\
& Evet & 1 & 4,3 & 2 & 8,3 \\
& Hayır & 22 & 95,7 & 22 & 91,7 \\
\multirow{4}{*}{ Kurs Süresi } & Toplam & 23 & 100,0 & 24 & 100,0 \\
& Hiç Gitmedi & 22 & 95,7 & 22 & 91,7 \\
& $1-3$ ay & - & - & 1 & 4,2 \\
& $4-6$ ay & 1 & 4,3 & - & - \\
& $10-12$ ay & - & - & 1 & 4,2 \\
& Toplam & 23 & 100.0 & 24 & 100,0 \\
\hline
\end{tabular}

Tablo 4'te görüldüğü gibi Deney ve Kontrol gruplarındaki öğrencilerin tamamına yakını İngilizce kursuna katılmamıştır. Deney grubunda İngilizce kursuna katılan 1 öğrencinin 4-6 ay arası kursa devam ettiği görülmektedir. Kontrol grubunda ise İngilizce kursuna katılan 2 öğrenciden biri, 1-3 ay, diğeri ise 10-12 ay süreyle kursa devam etmiştir.

Tablo 5. Deney ve kontrol gruplarında yer alan öğrencilerinin İngilizce dersi başarı dağııımları

\begin{tabular}{lrrrr}
\hline & \multicolumn{2}{c}{ Deney } & \multicolumn{2}{c}{ Kontrol } \\
\hline NOT & $f$ & $\%$ & $f$ & $\%$ \\
$0-49$ (FF) & 2 & 8,7 & 3 & 12,5 \\
$50-54$ (FD) & - & - & - & - \\
$55-59$ (DD) & 3 & 13,0 & 5 & 20,8 \\
$60-64$ (DC) & 3 & 13,0 & 5 & 20,8 \\
$65-74$ (CC) & 3 & 13,0 & 3 & 12,5 \\
$75-79$ (CB) & 6 & 26,1 & - & - \\
$80-84$ (BB) & 2 & 8,7 & 1 & 4,2 \\
$85-89$ (BA) & 1 & 4,3 & 1 & 4,2 \\
$90-100$ (AA) & 2 & 8,7 & 4 & 16,7 \\
DEVAMSIZ & 1 & 4,3 & 2 & 8,3 \\
Toplam & 23 & 100,00 & 24 & 100,0 \\
\hline
\end{tabular}

Tablo 5'teki not dağılımları, Deney ve Kontrol grubu öğrencilerinin 2008-2009 Akademik yılı Güz dönemine aittir. Buna göre; Deney grubunda yer alan öğrencilerin \%26,1'inin başarı ortalamaları 70-74 (CB) aralığında toplanmaktadır. Öğrencilerin \%13'ü 55-59 (DD); \%13'ü, 60-64 (DC) ve aynı şekilde \%13’ü de 65-69 (CC) aralığında notlar aldığı görülmektedir. Kontrol grubunda yer alan öğrencilerin başarı notları incelendiğinde ise; \%20,8'i 55-59 (DD) yine \%20,8'i 60-64 (DC) aralığında notlar aldığı görülmektedir. \%16,7'sinin not dağılımı ise 90-100 (AA) aralığında yer almaktadır.

\section{Grupların Denkliğinin Sağlanması}

Grupların seçiminde sınıflar arasındaki öğretim elemanı farklılığını önlemek amacıyla, aynı öğretim elemanı tarafından yürütülen sınıfların seçimi esas alınmıştır. Yanlılık olabilir endişesiyle araştırmacının kendisinin girdiği sınıflar kapsam dışı bırakılmıştır. Her iki sınıfta da aynı haftada, aynı 


\section{Öz-düzenleme Stratejileri Öğretiminin Öğrencilerin İngilizce Başarılarına ve Tutumlarına Etkisi}

sürede ve aynı konunun işlenmesine özen gösterilmiştir. Öğrenci sayıları açısından birbirine denk olan sınıflar seçilmiştir. Grupların denk olup olmadıklarını belirlemek amacıyla İngilizce dersi başarı puanları dikkate alınmış, İngilizce Hazırbulunuşluk Testi, Öz-Düzenleme Stratejileri Ölçeği, Tutum Ölçeği uygulanmıştır. Testlerin tümünde aritmetik ortalamaları arasında anlamlı bir fark bulunmayan iki bölüm seçilmiştir. Rastgele kura yoluyla Mobilya ve Dekorasyon Eğitimi Bölümü deney, Elektrik Eğitimi Bölümü kontrol grubu olarak belirlenmiştir. Bu testlerdeki puanlara ilişkin istatistikler şöyledir.

Deney ve kontrol gruplarının bir önceki döneme ait öğrencilerin İngilizce dersi başarı puanlarıyla ilgili istatistikler Tablo 6'da verilmiştir.

Tablo 6. Deney ve kontrol grubu öğrencilerinin İngilizce I not dağılımları

\begin{tabular}{lccccc}
\hline BÖLÜM & N & $\bar{X}$ & S & t & p \\
\hline Deney & 23 & 5,9565 & 2,402 &.-267 & .790 \\
\hline Kontrol & 24 & 6,1667 & 2,943 & & \\
\hline
\end{tabular}

$5.00=60-64$ (DC)

$6.00=65-74(C C)$

Tablo 6 incelendiğinde gruplara uygulanan bağımsız t testi sonuçlarına göre deney ve kontrol grubundaki öğrencilerin İngilizce başarı puan ortalamaları arasında anlamlı bir fark bulunmamıştır. Bu durum öğrencilerin bir önceki döneme ait İngilizce başarıları açısından farklı olmadığını göstermektedir.

Deney ve kontrol gruplarının İngilizce hazırbulunuşluk düzeyleri ilgili istatistikler Tablo 7’de verilmiştir.

Tablo 7. Deney ve kontrol grubu öğrencilerinin İngilizce hazırbulunuşluk testine ilişkin puanları

\begin{tabular}{lcrrrr}
\hline BÖLÜM & $\mathbf{N}$ & $\bar{X}$ & $\mathbf{S}$ & $\mathbf{t}$ & $\mathbf{p}$ \\
Deney & 23 & 31,347 & 6,485 & $-1,122$ &, 268 \\
\hline Kontrol & 24 & 34,125 & 10,023 & & \\
\hline
\end{tabular}

Tablo 7 incelendiğinde gruplara uygulanan bağımsız t testi sonuçlarına göre deney ve kontrol grubundaki öğrencilerin İngilizce hazırbulunuşluk düzeyleri arasında anlamlı bir fark bulunmamıştır. Bu durum öğrencilerin İngilizce hazırbulunuşluk düzeylerinin farklı olmadığını göstermektedir.

Deney ve kontrol gruplarının İngilizce dersine yönelik tutumları ilgili istatistikler Tablo 8'de verilmiştir.

Tablo 8. Deney ve kontrol grubu öğrencilerinin İngilizce tutum puanları

\begin{tabular}{lrrrrr}
\hline BÖLÜM & N & $\bar{X}$ & S & t & p \\
\hline Deney & 23 & 131,260 & 15,748 & .858 & .395 \\
\hline Kontrol & 24 & 126,375 & 22,523 & & \\
\hline
\end{tabular}

Tablo 8 incelendiğinde, gruplara uygulanan bağımsız $t$ testi sonuçlarına göre deney ve kontrol grubundaki öğrencilerin İngilizce dersine yönelik tutumları arasında anlamlı bir fark bulunmamıştır. Bu durum öğrencilerin İngilizce dersine yönelik tutumlarının farklı olmadığını göstermektedir. 


\section{Veri Toplama Araçları}

Öz-düzenleme stratejileri öğretiminin öğrencilerin İngilizce dersindeki başarılarına, özdüzenleme stratejileri kullanım düzeylerine ve İngilizce dersine yönelik tutumlarına etkisinin araştırıldığı bu çalışmada 3 veri toplama aracı kullanılmıştır. Bu araçlar, "Ingilizce Hazırbulunuşluk Testi, İngilizce Başarı Testi, İngilizce Tutum Ölçeği”dir. Veri toplama araçlarına ilişkin bilgiler aşağıda sunulmuştur.

\section{ingilizce Hazırbulunuşluk Testi}

Araştırmada öğrencilerin İngilizce I dersine ilişkin ön bilgilerini ölçmek ve grupların denkliğini belirlemek amacıyla, araştırmacı tarafından geliştirilen, "Ingilizce Hazırbulunuşluk Testi" kullanılmıştır. Bu test, bir önceki dönem olan İngilizce I Güz dönemi programının hedeflerini ölçen çoktan seçmeli 63 maddeden oluşmaktadır. Testin geçerliliğini ve güvenirliğini sağlamak amacıyla 3 konu alanı, 2 program geliştirme, 1 ölçme ve değerlendirme uzmanının görüşlerine başvurulmuştur. Aynı zamanda pilot uygulama çalışması yapılmıştır. Bu uygulama, İngilizce I dersini almış olan Teknik Eğitim Fakültesi 2. sınıfta öğrenim gören 173 öğrenciye bir ders süresince gerçekleştirilmiştir. Test istatistikleri sonucunda 63 maddelik testin aritmetik ortalaması ( $\bar{X}$ ) 38,2, standart sapması (S) 11,5, Güvenirliği KR 20=.91, test güçlüğü $P=.60$ olarak hesaplanmıştır. 63 madde olarak hazırlanan ingilizce Hazırbulunuşluk Testinin, madde güçlük indeksi ve madde ayırıcılık gücü hesaplanmıştır. Bu işlem sonucunda testten 8 madde çıkarılarak, test 55 maddelik son halini almıştır.

Nihai test maddelerinin analizleri yeniden yapılmış ve bu test uygulandığı takdirde alabileceği olası sonuçlar belirlenmiştir. Nihai Test ortalaması 33, Standard Sapma= 10,8, KR 20=.92 şeklinde bulunmuştur. Testin ortalama güçlüğü .60 şeklindedir. Elde edilen sonuçlar doğrultusunda, 55 maddelik Nihai testin geçerlilik ve güvenirliğinin uygun ve araştırmada kullanılabilir olduğu görülmektedir.

\section{Ingilizce Başarı Testi}

Araştırmanın deney ve kontrol grubunda yer alan öğrencilerin İngilizce II dersindeki akademik başarılarını ölçmek amacıyla, İngilizce II dersine yönelik olarak oluşturulan öğretim hedeflerine göre, araştırmacı tarafından 61 maddelik "Ingilizce Başarı Testi" hazırlanmıştır. Testin kapsam ve yapı geçerliliklerini belirlemek amacıyla 3 konu alanı, 2 program geliştirme, 1 ölçme ve değerlendirme uzmanının görüşlerine başvurulmuştur.

İngilizce Başarı Testinin pilot uygulaması, bir önceki akademik yılda İngilizce II dersini almış olan Teknik Eğitim Fakültesi 2. sınıfta öğrenim gören 153 öğrenciyle gerçekleştirilmiştir. Test istatistikleri sonucunda testin aritmetik ortalaması $(\bar{X}) 34$, Standard Sapma (S) 13.8, Testin varyansı (s) 192.084, 


\section{Öz-düzenleme Stratejileri Öğretiminin Öğrencilerin İngilizce Başarılarına ve Tutumlarına Etkisi}

Güvenirliği KR.20= .94, Test Güçlüğü $(P)=.55$, Madde Ayırıcılık Gücü. 48 olarak hesaplanmıştır. 61 madde olarak hazırlanan İngilizce Başarı Testinin, madde istatistiklerinde, madde güçlük indeksi (pj), madde varyansı (s), madde standart sapması (S), madde ayırıcılık gücü (rjx) hesaplanmış ve madde ayırıcılık gücü .30 'dan büyük olan maddeler seçilmiş, 6 madde çıkarılarak 55 maddelik çoktan seçmeli halini almıştır.

Nihai Test ortalaması 31, Standard Sapma $=13,4$, Testin Varyansı; 182.053, Güvenirlik KR 20=.92, Madde Güçlük: .57 ve Ortalama Ayırıcılık Gücü. 52 şeklinde hesaplanmıştır. Testin ortalama güçlüğü. 60 şeklindedir.

\section{ingilizce Tutum Ölçeği}

Araştırmada öğrencilerin İngilizce dersine ilişkin tutumlarını ölçmek amacıyla Selçuk (1997) tarafından geliştirilen "ingilizce Tutum Ölçeği” kullanılmıştır.

Ölçeğin hazırlanması aşamasında öğrencilerden elde edilen ifadeler, uzmanlar yardımıyla derlenmiş ve ölçekte İngilizce ile ilgili olabilecek bilişsel, duyuşsal ve eyleme yönelik öğelere yer verilmiştir. Ölçeğin Cronbach Alpha güvenilirlik katsayısı .94'tür.(Selçuk, 1997). Araştırma kapsamında İngilizce Tutum Ölçeğinin güvenirlik çalışması tekrar yapılmış, Cronbach Alpha değeri. 93 olarak bulunmuştur. Ölçek (1) Gerekliliğine inanma, (2) İngilizce dersine ilişsin duygular ve (3) Ders dışında ilgilenme olmak üzere 3 alt boyuttan oluşmaktadır.

\section{Verilerin Toplanması}

Araştırma, 2008-2009 Bahar Döneminde, İngilizce II dersinde, haftada 4'er saat olmak üzere, 8 haftada toplam 32 saat süresince yürütülmüştür. Araştırmada yanlılığı önlemek amacıyla her iki grubun İngilizce derslerini, araştırmacı dışında bir öğretim elemanı yürütmüştür. Araştırmacı hem süreci izlemek hem de etkinlikleri koordine etmek amacıyla derslere katılmıştır. Bu çalışmada, Pintrich'in Öz-düzenleme modeli temele alınmıştır (Pintrich; 1999). Bu model kapsamında özdüzenleme etkinliklerinden "Bilişsel, Biliş Bilgisi ve Öz-Düzenleme ve Kaynak Yönetimi Stratejileri" bulunmaktadır. Bu kapsamda, öz-düzenleme süreçleri, hedef belirleme, önceki bilginin ve biliş bilgisinin etkin hale getirilmesi şeklinde planlama safhasında başlamaktadır. Kendini izleme aşamasında, öğrencinin biliş, motivasyon, duygu, zaman ve çaba yönetimi, görev ve bağlamla ilgili durumunun farkına varması söz konusudur. Buna örnek olarak öğrencinin metni anlayıp anlamadığını sorgulaması, hızlı okuduğuna, daha çok çalışmaya veya yardım almaya karar vermesi verilebilir. Diğer yandan, kontrol safhasında ise bir önceki aşamanın sonuçları görülür. Uygun stratejilerin seçimi, zaman ve çaba yönetiminin düzenlenmesi, sınıf ortamının kontrol edilmesi bu safhada yapılır. Son olarak değerlendirme bölümünde ise, öğrencinin daha önceden oluşturduğu kriterlere göre bazı yargılara varması söz konusudur. Özet olarak Pintrich modelinde daha bütüncül ve kapsamlı bir çerçeve 
oluşturulmaya çalışılmıştır. Diğer modellerden farklı veya yeni olan tarafı ise; öz-düzenlemeye ilk olarak bağlamsal alanın eklenmesidir. Öğrencilerin bağlamlarını değiştirmek veya uyarlamak için bir şeyler yapabilecekleri ön planda tutulmuştur (Pintrich, 2000).

Bu araştırmada temel alınan model Pintrich'in öz-düzenleme modeli olduğu için stratejiler bu bağlamda açıklanmıştır. Uygulama öncesinde uygulamanın yapılacağı sınıfların dersine giren öğretim elemanı ile görüşülerek hangi hedefler ve içeriğin seçileceğine karar verilmiş ve öz-düzenleme stratejilerinin bütünleştirildiği haftalık etkinlikler hazırlanmıştır. Etkinliklerin, Ingilizce öğrenim hedeflerine, öğrenci seviyelerine ve öz-düzenleme stratejilerine uygunluğu açısından bir Eğitim Bilimleri Uzmanının görüşüne başvurulmuştur. Ayrıca etkinliklerin Deney grubunun öğrenim düzeyine ve belirlenen hedeflere uygunluğu açısından dersin öğretim elemanının görüşleri alınmıştır. Görüşler doğrultusunda, etkinlikler yeniden gözden geçirilerek son şekli verilmiştir. Öğretim elemanına, etkinliklerin uygulanışı ve materyallerin kullanımı ile ilgili gerekli eğitim verilmiştir. Etkinliklerden önce ders planları, ders araç ve gereçleri ve öğretim materyalleri hazır hale getirilmiştir.

Uygulama sürecinde, deney ve kontrol grubunda aynı hedef ve içeriğe ilişkin uygulamalar ve küçük sınavlar paralel haftalarda gerçekleştirilmiştir. Deney grubunda, öz-düzenleme stratejilerinin bütünleştirildiği etkinlikler uygulanmıştır. Deney ve kontrol gruplarına, İngilizce başarı testi ve İngilizce Tutum Ölçeği uygulama öncesi ve sonrası uygulanmıştır. İlk uygulamadan itibaren öğrencilere ait her türlü performans bir ürün dosyası olarak toplanmıştır. Bu durum, öğrencinin kendi gelişim sürecini izleyip değerlendirmesi için olanak sağlamış ve öğrencilerin zaman ve çaba ile ilgili düzenlemeler yapmalarına fırsat vermiştir. Öğrenci ürün dosyasında, öğrencilerin çalışma alışkanlıkları, yoğunlukları ve sıklıklarıyla ilgili değerlendirmeler yapmaları istenmiştir. Bu şekilde öğrencinin kendi zaman ve çaba yönetimini yönlendirme konusunda daha aktif kılınması hedeflenmiştir. Deney grubu öğrencilerine her hafta verilen ödevlere ilişkin geri bildirim sağlanmış ve takip eden haftalarda yanlışların azalmış olduğu gözlenmiştir. Ayrıca, öğrenciler eksik olan ödevlerin tamamlanmasıyla ilgili cesaretlendirilmişlerdir. Bu şekilde hem duyuşsal stratejilerin kullanımı sağlanmış ayrıca İngilizceye karşı olumsuz tutuma sahip olan öğrenciler için de olumlu bir etki amaçlanmıştır. Ödev kontrollerinin belirli aralıklarla akranlar aracılığıyla da yapılması sağlanmıştır.

Etkinlikler boyunca öğrenciler sıklıkla grup çalışmalarına yönlendirilmiştir. Öğrencilerin her bir grup çalışmasında aynı grupta bulunmamalarına özen gösterilmiştir. Bu sayede, hem öğrenciler arasındaki iletişimin arttırılması hem de yardım alma stratejisinin ders sonrası da kullanılması amaçlanmıştır.

Sonuç olarak her hafta düzenli olarak, tekrar stratejisi, eklemleme stratejisi, örgütleme stratejisi, içsel ve dışsal motivasyon stratejileri, biliş bilgisi stratejileri, öz-değerlendirme, akran yardımı, 


\section{Öz-düzenleme Stratejileri Öğretiminin Öğrencilerin İngilizce Başarılarına ve Tutumlarına Etkisi}

zaman, çalışma yönetimi, akran değerlendirme stratejilerine yönelik etkinlikler gerçekleştirilmiştir.

Sekiz hafta süreyle etkinliklerle bütünleştirilen öz-düzenleme stratejileri; konuyla bağlantı kurma, örgütleme, telafi, eklemleme, sistematik tekrar, altını çizme, akran öğrenme, akrandan yardım alma, öz ve akran değerlendirme, hedef belirleme, biliş bilgisi, çaba, zaman ve kaynak yönetimi, dışsal ve içsel motivasyon artırma, ilgi duyma ve çalışmaya değer bulma, çaba yönetimi ve güdülenmeye yönelik stratejiler şeklindedir.

Kontrol grubunun belirlenen konuya ilişkin dersleri, deney grubuna paralel olarak aynı haftalarda ve aynı sürede (8 hafta) gerçekleştirilmiştir. Kontrol grubunun dersleri aynı öğretim elemanı tarafından yürütülmüş ancak araştırmacı, dersin planlanması ve düzenlenmesi ile ilgili herhangi bir müdahalede bulunmamıştır. Öğretim elemanı kendi planlaması doğrultusunda derslerini yürütmüştür. Deney grubunda yapılan küçük sınavlar, aynı şekilde kontrol grubunda da yapılmıştır. Bu sayede kontrol grubu öğrencilerinin de İngilizce başarı gelişimleri araştırmacı tarafından izlenmiştir.

\section{Verilerin Analizi}

Araştırmada, nicel veri analizlerinden Kovaryans analizi (ANCOVA) yapılmıştır. Kovaryans analizinin amacı, bir araştırmada etkisi test edilen bir faktörün ya da faktörlerin dışında, bağımlı değişken ile ilişkisi bulunan bir değişkenin ya da değişkenlerin istatistiksel olarak kontrol edilmesini sağlamaktır (Büyüköztürk, 2010, 111). Kovaryans analizine genellikle ön test-son test kontrol gruplu desenlerde, deney ve kontrol grubunun son-test ölçümleri arasında anlamlı bir farkın olup olmadığını test etmek için başvurulmaktadır. Burada ön test ölçümleri ortak değişken olarak tanımlanmaktadır (Büyüköztürk, 1998). Bu araştırmada deney ve kontrol gruplarının ön test puanları kontrol altına alınarak uygulanan işlemin etkililiği son test sonuçlarına dayalı olarak hesaplanmıştır. Araştırmada anlamlılık düzeyi .05 olarak kabul edilmiştir.

\section{Bulgular}

Araştırmanın birinci amacl; "Deney ve Kontrol grubunun İngilizce başarı ön test puanları kontrol altına alındığında, son test puanları arasında anlamlı bir farklılık var mıdır? şeklinde ifade edilmiştir.

Deney ve Kontrol gruplarının İngilizce başarı ön-testinden aldıkları puanlara göre düzeltilmiş son test puanları Tablo 9'da verilmiştir. 
Tablo 9. Deney ve kontrol gruplarının İngilizce sontest puanlarının düzeltilmiş ortalamaları

\begin{tabular}{lcccc}
\hline Öntest & $\boldsymbol{N}$ & $\bar{X}$ & $\boldsymbol{S S}$ & Düzeltilmiş Ortalama \\
\hline Deney & 23 & 33,870 & 6,174 & 37,297 \\
Kontrol & 24 & 36,541 & 9,762 & 33,257 \\
\hline Toplam & 47 & 35,234 & 8,228 & \\
\hline
\end{tabular}

Tablo 9'da görüldüğü gibi; grupların ön test puanlarına göre düzeltilmiş son test puanları ortalaması Deney grubunda 37,30 olup, Kontrol grubunda ise bu değer; 33,2 olarak hesaplanmıştır. Düzeltilmiş ortalama puanları incelendiğinde deney grubunun başarı ortalamasının daha yüksek olduğu görülmektedir.

Grupların düzeltilmiş ortalama puanları arasındaki farkın anlamlı olup olmadığına ilişkin yapılan tek faktörlü kovaryans analizi (ANCOVA) sonuçları Tablo 10'da verilmiştir.

Tablo 10. Ingilizce başarı ön test puanlarına göre düzeltilmiş son test puanlarının gruba göre ANCOVA değerleri

\begin{tabular}{lccccc}
\hline $\begin{array}{l}\text { Varyansın } \\
\text { Kaynağı }\end{array}$ & $\begin{array}{l}\text { Kareler } \\
\text { Toplamı }\end{array}$ & sd & $\begin{array}{l}\text { Kareler } \\
\text { Ortalaması }\end{array}$ & $\boldsymbol{F}$ & $\boldsymbol{p}$ \\
\hline Ön test & 1516,39 & 1 & 1516,39 & 44,06 &, 000 \\
Grup & 142,07 & 1 & 142,07 & 4,13 &, 048 \\
Hata & 1514,176 & 44 & 34,413 & & \\
\hline Toplam & 3114,426 & 46 & & & \\
\hline
\end{tabular}

Tablo 10'da görüldüğü gibi deney ve kontrol gruplarının düzeltilmiş başarı son test ortalama puanları arasında deney grubu lehine anlamlı fark bulunmaktadır, $F(1,44)=4,13, p<.05$ Bu duruma göre, öz-düzenleme stratejilerinin kullanımı öğrencilerin İngilizce başarı düzeyini arttırmıştır.

Araştırmanın ikinci alt amacı "Deney ve Kontrol grubunun uygulama öncesi İngilizce dersine yönelik tutum ölçeğinden alınan puanları kontrol altına alındığında, uygulama sonrasında elde edilen ölçek puanları arasında anlamlı bir farklıık var mıdır?" şeklindedir.

Öğrencilerin İngilizceye yönelik tutumlarını belirlemek amacıyla kullanılan tutum ölçeğinden elde edilen uygulama öncesi ölçek puanlarına göre düzeltilmiş uygulama sonrası ölçek puanlarına ilişkin bulgular Tablo $11^{\prime}$.de verilmiştir.

Tablo 11. Deney ve kontrol gruplarının tutum puanlarının düzeltilmiş ortalamaları

\begin{tabular}{lcccc}
\hline Öntest & $\boldsymbol{N}$ & $\bar{X}$ & SS & Düzeltilmiş Ortalama \\
\hline Deney & 23 & 142,52 & 24,12 & 141,34 \\
Kontrol & 24 & 134,63 & 10,88 & 135,76 \\
\hline
\end{tabular}

Tablo 11'de görüldüğü gibi; grupların İngilizce tutum ölçeğinden aldıkları uygulama öncesi 


\section{Öz-düzenleme Stratejileri Öğretiminin Öğrencilerin İngilizce Başarılarına ve Tutumlarına Etkisi}

puanlarına göre düzeltilmiş uygulama sonrası puanları ortalaması Deney grubunda 141,34 olup, Kontrol grubunda ise bu değer; 135,76 olarak hesaplanmıştır. Düzeltilmiş ortalamalar incelendiğinde, Deney grubu puanlarının Kontrol grubundan daha yüksek olduğu görülmektedir.

Grupların düzeltilmiş ortalama puanları arasında gözlenen farkın anlamlı olup olmadığına ilişkin yapılan tek faktörlü kovaryans analizi (ANCOVA) sonuçları Tablo 11'de verilmiştir.

Tablo 11. Tutum ölçeğinin uygulama öncesi puanlarına göre düzeltilmiş uygulama sonrası puanlarının gruba göre ANCOVA değerleri

\begin{tabular}{llccrc}
\hline $\begin{array}{l}\text { Varyansın } \\
\text { Kaynağı }\end{array}$ & $\begin{array}{l}\text { Kareler } \\
\text { Toplamı }\end{array}$ & sd & $\begin{array}{c}\text { Kareler } \\
\text { Ortalaması }\end{array}$ & $\boldsymbol{F}$ & $\boldsymbol{p}$ \\
\hline Tutum & 3825,06 & 1 & 3825,06 & 14,39 & .001 \\
Grup & 360,77 & 1 & 360.77 & 1.36 & .250 \\
Hata & 11692,30 & 44 & 265.73 & & \\
\hline Toplam & $\mathbf{1 6 2 2 4 9 . 7 5}$ & $\mathbf{4 7}$ & & & \\
\hline
\end{tabular}

Kovaryans analizi (ANCOVA) sonuçlarına göre Deney ve Kontrol grubu öğrencilerinin İngilizce tutum ölçeği uygulama öncesi puanlarına göre düzeltilmiş uygulama sonrası ortalama puanları arasında anlamlı bir fark bulunmamıştır. $F(1,44)=1,36$ p $>05$.

\section{Tartışma}

Araştırmanın birinci amacı kapsamında öz-düzenleme stratejileri kullanımının öğrencilerin İngilizce başarısına etkisi araştırılmıştır. Bunun sonucunda, Ingilizce öğretiminde öz-düzenleme stratejileri kullanımına bağlı olarak öğrenci başarısının anlamlı düzeyde etkilendiği görülmüştür. Bu durum öğretmenlerin derslerinde öz-düzenleme stratejilerini öğretim uygulamalarına yansıttıklarında öğrencilerin akademik başarılarını etkileyebilecekleri şeklinde yorumlanabilir. Araştırmanın bu bulgusunu destekleyen çok sayıda çalışma bulunmaktadır.

Tekbıyık, Camadan ve Gülay (2013) yaptıkları çalışmada, ilköğretim öğrencilerinin Fen ve Teknoloji dersindeki akademik başarılarının, kullandıkları öz düzenleyici öğrenme stratejileri tarafından yordanmasını incelemişlerdir. Araştırmanın sonuçlarına göre; öz düzenleyici öğrenme stratejileri ile başarının anlamlı olarak ilişkili olduğu bulunmuştur.

Şahin ve Uyar (2013) yaptıkları araştırmalarında, öğrencilerin akademik başarılarının kullandıkları öğrenme stratejilerine göre anlamlı bir şekilde değiştiğini göstermektedir.

Mandacı Şahin (2010) tarafından yapılan çalışmada, sınıf öğretmeni adaylarının matematik öğretimi I ve II derslerindeki akademik başarıları ile öz düzenleme becerileri arasındaki ilişkinin incelenmesi amaçlanmıştır. Öğretmen adaylarının Matematik Öğretimi I ve II derslerinden aldıkları 
başarı notlarının analizi sonucunda; sınıf öğretmeni adaylarının Matematik Öğretimi dersindeki akademik başarıları ile öz-düzenleme becerileri arasında anlamlı bir farklılık olduğu belirlenmiştir.

Jing (2010) tarafından yapılan çalışmada deneysel araştırma ve nitel analizlere dayanılarak, yabancı dil olarak İngilizceyi öğrenen öğrencilerin kullandığı öğrenme stratejileri belirlenmeye çalışılmıştır. Özellikle biliş bilgisi, ezber ve bilişsel stratejilerin dil yeterliğindeki en kuvvetli olumlu etkiye sahip stratejiler olduğu sonucuna varılmıştır.

Çubukçu (2008), Pintrich'in modelinde öngörülen biliş bilgisi yoluyla izlemenin, diğer bilişsel stratejileri seçmede önemli olduğu görüşünü, İngilizce öğretmenliği bölümü öğrencileri üzerinde uyguladığı ön-test, son test kontrol gruplu deneysel çalışmada araştırmıştır. Deney grubunun kelime ön test puanları, kontrol grubundan yüksek olduğu için kovaryans analizi yapılmıştır. Bu analizin sonucunda, hem kelime hem de okuma testinde deney grubu lehine farklıık ortaya çıkmıştır.

Tok (2008)'un araştırmasında, öğrenme stratejilerinden, bil-iste-öğren ve not tutma stratejileri, ilköğretim 5. sınıf, Fen ve Teknoloji dersinde geleneksel öğretmen merkezli yöntemle karşılaştırılmış ve bunların akademik başarıya etkisi araştırımıştır. Kullanılan stratejilerin akademik başarıyı artırmada etkili olabileceği sonucuna ulaşılmıştır.

Camahalan (2006) araştırmasında, matematik dersiyle bütünleştirilen öz-düzenleme stratejilerini uygulayarak öğrencilerin matematik başarılarını artırmayı hedeflemiştir. Sonuç olarak özdüzenleme stratejileri açık bir şekilde aktarıldığında ve derste öğrencilere kendi inisiyatiflerini kullanma konusunda esnek şartlar sağlandığında, akademik başarıları olumlu şekilde etkilendiği görülmüştür.

Schloemer ve Brenan, (2006) çalışmalarında, üniversite öğrencilerine üç yıl süren özdüzenlemeyle bütünleştirilmiş muhasebe öğretiminin akademik başarıya etkisini araştırmışlardır. Verilen öğretim sonucunda, öğrencilerin akademik başarıları artmıştır.

Yapılan çalışmalar akademik düzeyde başarılı olan öğrencilerin diğerlerine kıyasla daha çok özdüzenleme stratejisi kullandığını ve aynı zamanda öğretmenlerinden daha çok yardım talep ettiğini ortaya koymaktadır. Ayrıca bu öğrenciler, bir sınavda ne derecede başarılı olduklarının daha çok bilincindedirler (Zimmerman and Martinez-Pons, 1986; 1988, Pape \& Wang, 2003; Akt. Chuan, 2004).

Yukarıda verilen araştırma sonuçlarıyla bu araştırmanın bulguları benzerlik göstermektedir. Sonuç olarak öz-düzenleme stratejileriyle bütünleştirilmiş derslerin, öğrencilerin akademik başarılarını artırmada olumlu etkisi olduğu söylenebilir.

Araştırmanın ikinci amacı kapsamında öğrencilerin, öz-düzenleme stratejilerine uygun olarak hazırlanan ders etkinliklerinin öğrencilerin İngilizce dersine yönelik tutumlarına etkisi araştırılmıştır. Elde edilen sonuçlara göre deney ve kontrol grupları arasında anlamlı bir farklılık bulunmamıştır. 


\section{Öz-düzenleme Stratejileri Öğretiminin Öğrencilerin İngilizce Başarılarına ve Tutumlarına Etkisi}

Bu sonuca paralel olarak Sarıbaş (2009) tarafından yapılan çalışmada, öz-düzenlemeye dayalı öğrenme stratejilerini geliştirmeye yönelik olarak tasarlanmış kimya laboratuvarı etkinliklerinin, başarı ve kimyaya karsı tutumları üzerine etkisi araştırımıştır. Araştırmanın sonunda deney grubundaki öğrenciler, değişkenleri tanımlayabilme ve işlemsel açıklamalar getirebilme boyutlarında kontrol grubundaki öğrencilere göre daha başarılı olmuşlardır ancak öğrenci tutumlarında anlamlı bir farklılık bulunamamıştır. Bu araştırmada da, öz-düzenleme stratejilerinin kullanımı, akademik başarılarını anlamlı bir şekilde etkilemiş, fakat tutumlarında anlamlı bir farklıık oluşturmamıştır. Bu bulgu Sarıbaş (2009)'un araştırma sonucuyla da benzerlik göstermektedir.

Tok (2008)'un araştırmasında, öğrenme stratejilerinden, bil-iste-öğren ve not tutma stratejileri, ilköğretim 5. sınıf, Fen ve Teknoloji dersinde geleneksel öğretmen merkezli yöntemle karşılaştırılmış ve bunların tutuma etkisi araştırılmıştır. Araştırmada, yarı deneysel desen kullanılarak 5 hafta süren bir uygulama yapılmıştır. Kullanılan stratejilerin öğrencilerin Fen ve Teknoloji dersine ilişkin tutumlarına etkili olmadığı sonucuna ulaşılmıştır.

Pintrich $(1995 ; 11)$ öğrencilere, öz-düzenleme stratejilerini sürekli olarak uygulanması gerektiğini, öz-düzenleme becerisine sahip olmak için bir gün, bir hafta veya bir dönemin bile yeterli olamadığını, bu stratejilerin geliştirilmesi için zaman ve fırsat oluşturulması gerektiğini ifade etmektedir. Aynı zamanda, sadece bir derste bu stratejilerin kullanılmasının yeterli olmadığını, tüm öğretim elemanlarının öğrencilere yanlış yaptıkları noktalarla ilgili dönüt vermesi ve öz-düzenlemeyle öğrenmeyle ilgili rehberlik etmesi gerektiğini belirtmiştir.

Arsal (2010) tarafından yapılan deneysel araştırmada, fen bilgisi öğretmen adaylarının tuttuğu günlüklerin, öz-düzenleme stratejilerine olan etkisi, Pintrich'in öz-düzenleme modeli temel alınarak belirlenmiştir. Sonuçlara göre, deney ve kontrol grubu arasında dışsal motivasyon, inanç kontrolü, özyeterlik, sınav kaygısı ve çabaya yönelik anlamlı bir farklılık oluşmamıştır. Fakat içsel motivasyon ve görev değeriyle ilgili anlamlı bir farklılık tespit edilmiştir.

Bu araştırmada, öğretim sürecinde kullanılan öz-düzenleme stratejilerinin, öğrencilerin öz düzenleme becerilerinde ve tutumlarında anlamlı düzeyde bir etkiye yol açmamasının nedenlerinden birisi, uygulama süresinin bireye beceri ve tutum kazandırmada yeterli olmaması olabilir. Ayrıca, araştırmacının öz-düzenleme stratejilerini doğrudan öğrencilere kazandırmak amacı taşımaması ve yalnızca öğretim süreci uygulamalarıyla bütünleştirmesi diğer bir neden olarak gösterilebilir.

Araştırma sonucunda aşağıdaki öneriler getirilmiştir.

Öğretmenler, öğretim süreci uygulamalarını planlarken, öz-düzenleme stratejilerini içeren uygulamalar gerçekleştirmelidirler. Aynı zamanda, öğrencilerin yaşam boyu öğrenme kapsamında etkili olan, hedef belirleme, uygun stratejiyi seçme, kendini izleme ve değerlendirme vb. stratejileri 
kullanmaları, onların öğrenmede bağımsızlık kazanmalarına katkı sağlayacaktır.

Her öğrenci üniversiteye, strateji kullanımı veya akademik zorluklarla baş edebilme becerileriyle gelmeyebileceği düşünülerek, özellikle ilk yıl, öğretim elemanlarının derslerinde özdüzenleme stratejilerini kullanmaları, öğrencilerini hedef belirleme, kendilerindeki eksikleri bulma, gereken yardımı alma, kendi başarılarını izleme ve öz-değerlendirme yapmaları konularında bilgilendirmeleri ve cesaretlendirmeleri gerekmektedir.

İngilizcenin dört temel becerisi olan dinleme, konuşma, yazma ve okuma alanları, özdüzenleme stratejileriyle bütünleştirilmiş uygulamalarda belirgin olarak kullanılmalıdır.

Öz-düzenlemenin, doğrudan veya dersle bütünleştirilerek uygulandığı ve hem nicel hem de nitel çeşitli ölçme araçlarının kullanıldığı, kısa ve uzun vadeli hedeflerin öğrenciler tarafından seçildiği, öğrencilerin kendi öğrenmelerini izleyip değerlendirdiği yabancı dil uygulamaları yapılabilir.

\section{Kaynakça}

Arends, R. I. (1997). Classroom instruction and management. New York: The McGraw-Hill Companies, Inc.

Arsal, Z. (2010). The effects of diaries on self-regulation strategies of preservice science teachers. International Journal of Environmental \& Science Education, 5(1), 85-103.

Baharom S. (2003). Describing pre-university students' learning strategies using the rasch Model Proceeding of NZARE AARE Conference Educational Research, Risks, \& Dilemmas (29 November - 3 December, Auckland), New Zealand.

Büyüköztürk, Ş., Çakmak, E.K, Akgün, Ö.E, Karadeniz, Ş. ve Demirel, F. (2010). Bilimsel araştırma yöntemleri. Ankara: Pegem Akademi.

Büyüköztürk, Ş (1998). Kovaryans analizi: varyans analizi ile karşılaştırmalı bir inceleme. Ankara Üniversitesi Eğitim Bilimleri Fakültesi Dergisi, 31 (1)(91-105).

Camahalan F. M. G. (2006). Effects of self-regulated learning on mathematics achievement of selected Southeast Asian Children. Journal of Instructional Psychology, 33(3), 194-205.

Chen, C.S. (2002). Self-regulated learning strategies and achievement in an introduction to information systems course, Information Technology, Learning, and Performance Journal, Vol. 20, No. 1, Spring.

Cheng, E. C. K. (2011). The role of self-regulated learning in enhancing learning performance. The International Journal of Research and Review, 6(1), 1-16.

Chuan, W. (2004). Self-regulated learning strategies and self-efficacy beliefs of children learning english as a second language. The Ohio State University, Unpublished Doctoral Thesis, Columbus, Ohio.

Çubukçu, F. (2008). Enhancing vocabulary development and reading comprehension through metacognitive strategies. Issues in Educational Research, 18(1), 1-11.

Dörnyei, Z. (2005). The Psychology of the Language Learner. Individual Differences in Second Language Acquisition. UK: Psychology Pres, Taylor and Francis Group.

Drmrod, J.E. 1990). Human learning. Macmillan P. Company. New York.

Flavell, J. H. (1979). Metacognition and cognitive monitoring: A new area of cognitive-developmental inquiry. American Psychologist, 34 (10), 906-911.

Hacker, D. J., Dunlosky, J., Graesser, A. C. ( ed. ) (1998). Metacognition in Eductional Theory and Practice. Mahwah, NJ. Lawrence Erlbaum Associates, Publishers.

Hofer, B. K., Yu, S. L., \& Pintrich, P. R. (1998). Teaching college students to be self-regulated learners. In D. Schunk 


\section{Öz-düzenleme Stratejileri Öğretiminin Öğrencilerin İngilizce Başarılarına ve Tutumlarına Etkisi}

\& B. Zimmerman (Eds.), Self-regulated learning: From teaching to self-reflective practice (pp. 57-85). New York: The Guilford Press.

Jing, L. (2010). A study on language learning strategies among the instructed EFL learners. US-China Foreign Language, 8(3), 36-39.

Kaptan, S. (1995). Bilimsel araştırma ve istatistik teknikleri. Ankara: Bilim Kitapları

Leaver, B. L., Ehrman, M. E., \& Shekhtman, B. (2005). Achieving success in. second language acquisition. Cambridge: Cambridge University Pres.

Lens, W. And Vansteenkiste, M. (2007). Motivation and self-regulated learning: theory, research, and applications. In B. J. Zimmerman \& D. H. Schunk (eds.), Motivation and Self-Regulated Learning: Theory, Research, and Applications (pp. 141-168). Mahwah, NJ: Erlbaum.

Macaro, E. (2001). Learning strategies in foreign and second language classrooms. London and New York: Continuum.

Mandacı Şahin, S. (2010). Sınıf öğretmeni adaylarının matematik öğretimi derslerindeki akademik başarıları ile öz düzenleme becerileri arasındaki ilişki. 9. Ulusal Sınıf Öğretmenliği Eğitimi Sempozyumunda sunulan bildiri (20 -22 Mayıs,, Elazığ, ss. 256-260)

Pajares, F. (2007). Motivational role of self-efficacy beliefs in self-regulated learning. In B. J. Zimmerman \& D. H. Schunk (Eds.), Motivation and self-regulated learning: theory, research, and applications (pp. 111-139). Mahwah, NJ: Erlbaum.

Pintrich, P. (1999). The role of motivation in promoting and sustaining self-regulated learning. International Journal of Educational Research, 31(6), 459-470.

Pintrich P., Smith D., Garcia T., McKeachie W. (1991). A Manual for the Use of the Motivated Strategies for Learning Questionnaire. Technical Report 91-B-004. The Regents of The University of Michigan

Pintrich, P.R, Smith, D.A.F., Garcia, T. ve McKeachie, W.J. (1991). Self-regulated learning strategies. (http://jan.ucc.nau.edu, 20.08.2011 tarihinde erişildi).

Pintrich, P. R. (1995). Understanding self-regulated learning. In Menges R. J.\& Svinicki, M. D. (eds.), New directions for teaching and learning (Vol. 63, pp. 3-12). San Francisco: Jossey-Bass.

Pintrich, P. R. (1999). The role of motivation in promoting and sustaining self-regulated learning. Journal of Educational Research, 31, 459-470.

Pintrich, P. R. (2000). The role of goal orientation in self-regulated learning. In M., Boekaerts, \& P. R., Pintrich. (eds.) Handbook of self-regulation (pp.451-502). San Diego: Academic Press.

Pintrich, R. R. (2000). The role of goal orientation in self-regulated learning. In Boekaerts, M., Pintrich, P. R., ve Zeidner, M. (ds.), Handbook of Self- regulation, (pp. 451-501), San Diego, CA: Academic Press.

Rosenshine, B.V. (1997). The case for explicit, teacher-led, cognitive strategy instruction, Paper presented at the Annual Meeting of the American Educational Research Association, Chicago, IL. March 24-28.

Sarıbaş, D. (2009). Öz-düzenlemeye dayalı öğrenme stratejilerini geliştirmeye yönelik laboratuar ortamının kavramsal anlama, bilimsel işlem becerisi ve kimyaya karşı tutum üzerindeki etkisinin incelenmesi. Yayımlanmamış Doktora Tezi, İstanbul: Marmara Üniversitesi Eğitim Bilimleri Enstitüsü.

Schloemer, P., \& Brenan, K. (2006). From students to learners: Developing self-regulated learning. Journal of Education for Business, 82(2), 81-87.

Schunk, D. H., \& Pajares, F. (2005). Competence perceptions and academic functioning. In A. J. Elliot \& C. S. Dweck (Eds.), Handbook of competence and motivation (pp. 85-104). New York: Guilford Publications.

Selçuk, E. (1997). Ingilizce dersine karşı tutum ile bu dersteki akademik başarı arasındaki ilişki. Yayımlanmamış Yüksek Lisans Tezi, Bolu: Abant İzzet Baysal Üniversitesi Sosyal Bilimler Enstitüsü.

Şahin, H. Ve Uyar, M. (2013). Öğrenme Stratejileri Kullanımının Akademik Başarıya Yansımaları, Abant Izzet Baysal Üniversitesi Eğitim Fakültesi Dergisi, Cilt 13, Sayı , s.164-177

Tekbıyık, A., Camadan, F. ve Gülay A. (2013). Fen ve teknoloji dersinde akademik başarının yordayıcısı olarak öz düzenleyici öğrenme stratejileri, Turkish Studies - International Periodical For The Languages, Literature 
and History of Turkish or Turkic Volume 8/3, Winter 2013, p. 567-582.

Tok, Ş. (2008). Not tutma ve bil-iste-öğren (biö) stratejilerinin tutum ve akademik başarıya etkisi. Hacettepe Üniversitesi Eğitim Fakültesi Dergisi (H. U. Journal of Education), 34, 244-253.

Tseng, W, Dörnyei, Z and Schmitt, N. (2006). A new approach to assessing strategic learning: the case of selfregulation in vocabulary acquisition. Applied Linguistics, 27 (1), 78-102.

Turingan, J.P., Yang Y-C. (2009). A cross-cultural comparison of self-regulated learning skills between korean and filipino college students, Asian Social Science, 5(12), 3-10.

Weinstein, C.E., \& Mayer, R.E. (1986). The teaching of learning strategies. In M.Wittrock (ed.), Handbook of research on teaching. New York, NY: Macmillan.

Zimmerman, B.J. (2001). Theories of self-regulated learning and academic achievement: an overview and analysis. In Zimmerman, B.J. \& Schunk, D.H. (eds.), Self-regulated learning and academic achievement: theoretical perspectives (pp. 1-65) Mahwah, NJ: Lawrence Erlbaum Associates, Publishers.

Zimmerman, B. \&Schunk, D.H. (2007). Motivation, an essential dimension of self regulated learning. In D. H. Schunk \& B. Zimmerman (eds.), Motivation and self-regulated learning: theory, research, and applications (pp. 1-30) Mahwah, NJ: Erlbaum. 